\title{
PENDEKATAN SAINTIFIK UNTUK MENGEMBANGKAN KARAKTER DISIPLIN DAN TANGGUNG JAWAB SISWA SD
}

\author{
Aan Yuliyanto, Agistia Fadriyah, Karisa Puspa Yeli, Hayani Wulandari \\ Pendidikan Guru Sekolah Dasar, Universitas Pendidikan Indonesia, Kampus Purwakarta
}

\section{Kata Kunci :}

Pendekatan Saintifik

Disiplin

Tanggung Jawab
Email penulis:

aanyuliyanto@student.upi.edu

\begin{abstract}
Discipline and responsibility are the values of character that are sufficiently highlighted today. The objective of this research is to develop the character of discipline and responsibility of students by applying scientific approach in elementary school. This study was conducted due to the number of cases or phenomenon of students who showed lack of discipline and responsibility for both themselves and in the presence of others. This research will explore the formation of the character of discipline and student responsibility through a scientific approach. The quasi-experimental method is a method by using experimental class and control class to see the influence of the Scientific Approach to the character of discipline and student responsibility. The results of this study indicate that the scientific approach can develop the character of discipline and student responsibility and better than the conventional approach.
\end{abstract}

\section{PENDAHULUAN}

Pendidikan adalah usaha sadar dan terencana untuk mewujudkan suasana belajar dan proses pembelajaran agar peserta didik secara aktif mengembangkan potensi dirinya untuk memiliki kekuatan spiritual keagamaan, pengendalian diri, kepribadian, kecerdasan, akhlak mulia, serta keterampilan yang diperlukan dirinya, masyarakat (Dikbud, 2003), sedangkan tujuan Pendidikan Nasional untuk mengembangkan potensi peserta didik agar menjadi manusia yang beriman dan bertaqwa kepada Tuhan Yang Maha Esa, berakhlak mulia, sehat, 
berilmu, cakap, kreatif, mandiri, dan menjadi warga negara yang demokratis, serta bertanggung jawab (Depdiknas, 2003).

Menurut pengertian dan tujuan pendidikan nasional yang telah jabarkan, pendidikan nasional bertujuan membentuk pribadi siswa yang memiliki karakter bertanggung jawab dengan menanamkan norma-norma dan nilai-nilai kepada mereka. Untuk dapat mematuhi normanorma serta nilai yang berlaku dibutuhkan sikap disiplin yang tercipta dalam pribadi masingmasing siswa.

Menurut Aulina (2013, hlm. 37) menyatakan bahwa "disiplin merupakan kebutuhan mutlak di masa kanak-kanak mengingat masa ini merupakan masa yang paling efektif untuk pembentukan perilaku anak. Setiap anak memiliki potensi memahami aturan yang berkembang pada setiap tahap kehidupannya". Sedangkan menurut Ulum dan Wulandari (2013, hlm. 254) mengungkapkan bahwa "tanggung jawab adalah kesadaran manusia akan tingkah laku atau perbuatannya yang disengaja maupun yang tidak disengaja". Akhir-akhir ini sering terjadi perilaku menyimpang oleh siswa seperti kabur saat jam pelajaran di kelas berlangsung, mengambil barang yang bukan miliknya, atau sengaja melukai teman sebaya yang dilakukan oleh anak bahkan dewasa. Perilaku menyimpang terjadi karena kurangnya tanggung jawab dan disiplin terhadap diri sendiri.

Salah satu kasus pembinaan disiplin yang berbau kekerasan terjadi di Sekolah Dasar Sisir Kota Batu Malang. Dengan dalih membentuk kedisiplinan siswa selama belajar di kelas, seorang guru 'memplester' mulut siswanya yang 37 membuat gaduh di kelas (Aulina, 2013, 36-37). Pada tanggal 4 Februari 2012, telah terjadi tawuran antar pelajar yang mana tawuran tersebut dilakukan di saat proses pembelajaran sedang berlangsung, di sana para siswa SMA Kartika bolos sekolah pada jam pembelajaran, lalu mereka berkumpul dan melakukan tawuran terhadap para siswa sekolah lain yang sedang berada di jalan raya Jalan Permindo Kota Padang (Padang Ekspres 5 Februari 2012). Tambahan dari Mulyasa (2014, hlm. 1314) mejabarkan permasalahan pendidikan kita saat ini terkait karakter bangsa di antaranya:

Hampir setiap hari, kita disuguhi contoh-contoh yang menyedihkan melalui film dan televisi, yang secara bebas mempertontonkan perilaku sadisme, mutilasi, kekerasan, premanisme, kejahatan, perselingkuhan, kawin siri, penyalahgunaan obat terlarang dan korupsi yang telah membudaya dalam sebagian masyarakat bahkan dikalangan pejabat dan artis. Kita juga mendengar, melihat, dan menyaksikan, betapa para pemuda, pelajar, dan mahasiswa yang diharapkan menjadi tulang punggung bangsa telah terlibat dalam VCD porno, pelecehan seksual, narkoba, geng motor dan perjudian.

Bukti banyak kasus penyimpangan nilai moral di kalangan siswa SD seperti tidak patuh pada aturan kelas dan sekolah, bermain dan berbicara saat guru menjelaskan materi, membolos, berkata kasar atau tidak sopan dengan teman, berkelahi, membuang sampah sembarangan, hadir tidak tepat waktu, dan tidak menyelesaikan tugas atau tidak mengerjakan PR. (Apriani dan Wangid, 2015, hal.14)

Melihat permasalahan yang telah diungkapkan, pendidikan karakter sangat diperlukan untuk kehidupan bangsa yang kini mendapat pengaruh oleh era globalisasi, kemajuan teknologi dan informasi sera gaya hidup masyarakat yang dapat dikatakan hedonisme. Berkaitan dengan hal tersebut maka, pemberlakuan kurikulum 2013 oleh Kemendiknas dari tingkat SD diharapkan menjadi langkah yang baik untuk dapat mewujudkan siswa yang berkarakter (Apriani dan Wangid, 2015). Seperti diketahui, Kurikulum 2013 menggunakan Pendekatan Saintifik dalam pembelajarannya.

Pembelajaran dengan metode saintifik memiliki karakteristik sebagai berikut: 1) berpusat pada siswa, 2) melibatkan keterampilan proses sains dalam mengonstruksi konsep, hukum 
atau prinsip, 3) melibatkan proses-proses kognitif yang potensial dalam merangsang perkembangan intelek, khususnya keterampilan berpikir tingkat tinggi siswa, 4) dapat mengembangkan karakter siswa (Sumayasa, Marhaeni, dan Dantes. 2015, hlm. 4).

Metode ilmiah merupakan sebuah sebutan lain untuk pendekatan saintifik hal tersebut tecatat pada tulisan Joyce, \& Weil (dalam Apriani dan Wangid, 2015) menjelaskan bahwa 'metode ilmiah dapat diajarkan dan memiliki efek positif pada perolehan informasi, konsep, dan sikap. Artinya, pendekatan ilmiah diyakini mampu mengembangkan ranah sikap, keterampilan, dan pengetahuan siswa dengan tujuan mengembangkan good character'. Berdasarkan penjelasan tersebut peneliti berinisiatif melakukan penelitian tentang upaya pendekatan saintifik dalam mengembangkan karakter disiplin dan tanggung jawab pada siswa di Sekolah Dasar

Secara umum rumusan masalah dalam penelitian ini adalah "Apakah penerapan Pendekatan Saintifik dapat mengembangkan karakter disiplin dan tanggung jawab pada siswa kelas III SD?". Secara khusus rumusan masalah dalam penelitian ini yaitu, 1) Bagaimanakah karakter disiplin dan tanggung jawab siswa selama penerapan Pendekatan Saintifik?, 2) Apakah pengembangan karakter disiplin dan tanggung jawab siswa kelas III SD yang mendapat pembelajaran dengan Pendekatan Saintifik lebih baik dari siswa yang mendapat pembelajaran dengan pendekatan konvensional?

Tujuan khusus dari penelitian ini adalah menganalisis aktivitas belajar siswa selama penerapan Pendekatan Saintifik terhadap karakter disiplin dan tanggung jawab siswa pada pembelajaran tematik di kelas III SD, dan menganalisis pengembangan karakter disiplin dan tanggung jawab siswa kelas III SD yang mendapatkan pembelajaran dengan Pendekatan Saintifik dan yang mendapatkan pembelajaran dengan pendekatan konvensional.

\section{KAJIAN TEORITIK}

Penelitian ini akan membahas mengenai, pendekatan saintifik, pendekatan konvensional, karakter disiplin dan tanggung jawab, berikut ulasannya:

\section{Pendekatan Saintifik}

Pendekatan saintifik merupakan pendekatan yang tergolong baru diterapkan setelah adanya perubahan kurikulum, menurut Maryani dan Fatmawati (2016, hlm. 2) berpendapat dalam bukunya bahwa "pendekatan saintifik dimaksudkan untuk memberi pemahaman kepada peserta didik dalam mengenal, memahami berbagai materi menggunakan pendekatan ilmiah, bahwa insformasi bisa berasal dari mana saja, kapan saja, tidak bergantung pada informasi searah dari guru". Lebih lanjut Marjan, Arnyana, Setiawan (2014) mengungkapkan pengertian pendekatan saintifik dalam penelitiannya bahwa "Pendekatan pembelajaran menekankan pada keaktifan siswa dalam belajar, serta memberikan kesempatan kepada siswa untuk membangun konsep dalam pengetahuannya secara mandiri, membiasakan siswa dalam merumuskan, menghadapi, dan menyelesaiakan permasalah yang ditemukan"

Dapat ditarik kesimpulan mengenai Pendekatan Saintifik yaitu pendekatan dengan menggunakan keterampilan proses ilmiah yang memberikan kesempatan bagi siswa untuk aktif dalam proses pembelajaran dengan cara menemukan, mengidentifikasi, membangun sendiri yang mereka pelajari dengan guru sebagai fasilitator, tanpa penjelasan materi oleh guru secara langsung.

Adapun langkah kegiatan yang dilakukan melalui Pendekatan Saintifik di antaranya proses pembelajaran yang mengarah pada pembelajaran ilmiah, menurut Kementerian Pendidikan dan Kebudayaan (dalam Sufairoh, 2016, hlm. 120-121) berpendapat langkah pendekatan saintifik meliputi lima langkah, yaitu: 
"mengamati, menanya, mengumpulkan data, mengasosiasi, dan mengkomunikasikan”. Secara gambling menurut Petunjuk Teknis Pendekatan Saintifik Kurikulum 2013 Permendikbud 81 A Tahun 2013 (dalam Wartini dkk, 2014) adalah sebagai berikut: (a) Mengamati yakni alam kegiatan mengamati, guru membuka secara luas dan bervariasi kesempatan peserta didik untuk melakukan pengamatan melalui kegiatan: melihat, menyimak, mendengar, dan membaca; (b) Menanya yakni dalam kegiatan mengamati, guru membuka kesempatan secara luas kepada peserta didik untuk bertanya mengenai apa yang sudah dilihat, disimak, dibaca atau dilihat; (c) Mengumpulkan informasi/eksperimen yakni tindak lanjut dari bertanya adalah menggali dan mengumpulkan informasi dari berbagai sumber melalui berbagai cara; (d) Mengasosiasikan/mengolah informasi, yaitu Informasi tersebut menjadi dasar bagi kegiatan berikutnya yaitu memeroses informasi untuk menemukan keterkaitan satu informasi dengan informasi lainnya, menemukan pola dari keterkaitan informasi dan bahkan mengambil berbagai kesimpulan dari pola yang ditemukan; dan (e) Mengkomunikasikan yaitu kegiatan menuliskan atau menceritakan apa yang ditemukan dalam kegiatan mencari informasi, mengasosiasikan dan menemukan pola"

Pembelajaran dengan pendekatan saintifik adalah proses pembelajaran yang dirancang sedemikian rupa agar siswa secara aktif mengkonstruksi konsep, hukum dan prinsip melalui tahapan-tahapan atau yang dikenal dengan sebutan $5 \mathrm{M}$ yaitu mengamati, menanya, menalar, mencoba, dan mengkomunikasikan. (Batmalo, 2016, hlm. 473).

Dari penjabaran di atas dapat disimpulkan bahwa langkah Pendekatan Saintifik terdiri dari $5 \mathrm{M}$ yaitu mengamati, menanya, mencoba, menalar, dan mengkomunikasikan atau membuat jejaring.

Tujuan pembelajaran dengan pendekatan saintifik didasarkan pada keunggulan pendekatan tersebut, antara lain: (1) meningkatkan kemam $\neg$ puan intelek, khususnya kemampuan berpikir tingkat tinggi, (2) untuk membentuk kemampuan siswa dalam menyelesaikan suatu masalah secara sistematik, (3) terciptanya kondisi pembelajaran dimana siswa merasa bahwa belajar itu merupa-kan suatu kebutuhan, (4) diperolehnya hasil be-lajar yang tinggi, (5) untuk melatih siswa dalam mengomunikasikan ide-ide, khususnya dalam menulis artikel ilmiah, dan (6) untuk mengem $\neg$ bangkan karakter siswa. (Machin, 2014, hlm, 28-29). Lebih lanjut Sulastri (2015, hlm. 71) menjelaskan tentang kelebihan dari Pendekatan Saintifik, yaitu: (a) Para siswa akan lebih kritis dalam memahami sebuah konsep pembelajaran; (b) Memberikan rasa ingin tahu yang tinggi terhadap siswa untuk lebih menggali informasi; (c) Siswa akan berperan lebih aktif dalam sebuah pembelajaran, di mana mereka tidak hanya terpaku pada buku atau berdiam diri mendengarkan guru mengajar; dan (d) Menstimulasi siswa untuk lebih aktif dalam sebuah pembelajaran.

Betapa pentingnya pendekatan saintifik digunakan dalam pembelajaran di kelas, karena pendekatan saintifik dapat mengembangkan berbagai skill se $\neg$ perti keterampilan berpikir kritis (critical thinking skill), keterampilan berkomunikasi (communication skiI), keterampilan melakukan kerja sama dan penyelidikan (research and collaboration skill) dan perilaku berkarakter, karena pengalaman belajar yang diberikan dapat memenuhi tujuan pendidikan dan bermanfaat bagi pemecahan masalah dan kehidupan nyata. (Machin, 2014, hlm, 28-29). Selain kelebihan, Pendekatan Saintifik juga memiliki kekurangan seperti yang dijabarkan oleh Hosnan (2014), yaitu: (a) Bantuan guru berkurang sehingga guru jarang menjelaskan; (b) Dapat menghambat laju pembelajaran yang menyita waktu pembelajaran; (c) Kegagalan dan kesalahan dalam bereksperimen akan berakibat pada kesalahan penyimpulan; dan (d) Apabila minat siswa kurang terhadap materi dan tidak berkonsentrasi atau memecah perhatian peserta dapat menyebabkan pengajaran dilakukan tidak efektif. 
Berdasarkan pemaparan di atas dapat disimpulkan bahwa kelebihan Pendekatan Saintifik yaitu memberikan kesempatan bagi siswa untuk aktif dan belajar mandiri menemukan dan melakukan proses pembelajarannya sendiri dengan kegiatan ilmiahnya, melatih berpikir tingkat tinggi siswa, melatih komunikasi siswa, sedangkan kekurangannya yaitu peran guru dalam pembelajaran kurang karena guru hanya sebagai fasilitator dan dapat terjadinya kesalahpahaman siswa apabila guru kurang membimbing.

\section{Pendekatan Konvensional}

Pembelajaran konvensional adalah pembelajaran yang biasa dipakai guru dalam pembelajaran salah satunya adalah metode verbal, yakni metode ceramah (Lubis, 2012, hlm. 28). Yantiani, Wiarta, Putra (2013) menambahkan "pembelajaran konvensional adalah pembelajaran sebagaimana umumnya guru mengajarkan materi kepada siswanya. Guru mentransfer ilmu pengetahuan kepada siswa, sedangkan siswa hanya sebagai penerima. Dalam pembelajaran konvensional didominasi oleh metode ceramah". Melihat pemaparan di atas maka dapat disimpulkan bahwa pendekatan pembelajaran konvensional adalah pembelajaran yang berpusat pada guru dan umumnya menggunakan metode ceramah.

\section{Tanggung Jawab}

Tanggung jawab merupakan salah satu dari nilai-nilai karakter yang sangat lekat dalam diri manusia, menurut Lickona (2015, hlm 72) berpendpat bahwa "tanggung jawab secara literal berarti kemampuan untuk merespon atau menjawab." Itu artinya tanggung jawab berorientasi terhadap orang lain, memberikan bentuk perhatian, dan secara aktif memberikan respon terhadap apa yang mereka inginkan”. Apriani dan Wangid (2015) mendefinisikan tanggung jawab sebagai "berani, siap, dan teguh hatinya dalam menerima putusan dan tindakan yang dilakukan secara sengaja atau tidak sengaja, maksudnya, siswa dikatakan bertanggung jawab jika dirinya sadar mengambil keputusan dan mau menghadapi segala akibat yang terjadi”. Berikutnya Balitbang, Puskur (dalam Dyahwati, Rahayu, Susanti, 2013, hlm. 30-31).karakter tanggung jawab yaitu "sikap dan perilaku seseorang untuk melaksanakan tugas dan kewajibannya, yang seharusnya dia lakukan, terhadap diri sendiri, masyarakat, lingkungan (alam, sosial dan budaya) dan Tuhan Yang Maha Esa". Lebih lanjut Menurut Kemendiknas (dalam Prasetya, 2014) mendeskripsikan tanggung jawab sebagai:

"Sikap dan perilaku seseorang untuk melaksanakan tugas dan kewajibannya, yang seharusnya dia lakukan, terhadap diri sendiri, masyarakat, lingkungan (alam, sosial dan budaya), negara dan Tuhan Yang Maha Esa. Tanggung jawab juga menjadi salah satu aspek kompetensi yang harus dimiliki oleh siswa Sekolah Dasar atau sederajat yang tercantum dalam PERMENDIKNAS Nomor 20 Tahun 2006 tentang Standar Kompetensi Lulusan Sekolah Dasar dan Menengah. Dalam Bab II dijelaskan bahwa kompetensi lulusan Sekolah Dasar atau sederajat adalah memiliki perilaku yang mencerminkan sikap: beriman dan bertakwa kepada Tuhan Yang Maha Esa; berkarakter, jujur, dan peduli; bertanggung jawab; pembelajar sejati sepanjang hayat, dan; sehat jasmani dan rohani sesuai dengan perkembangan anak di lingkungan keluarga, sekolah, masyarakat dan lingkungan alam sekitar, bangsa, dan negara."

Selanjutnya menurut Putra, Thahar, dan Nurizzati (2013) berpendapat bahwa "tanggung jawab merupakan suatu tindakan yang menjadi wajib dilaksanakan atau dikerjakan sesuai hak yang diterima dan bersedia menerima baik dan buruk dari hasil pekerjaan yang dilaksanakan tersebut”. Kemudian Pasani, Sumartono, Sridevi (2016) berpendapat bahwa "tanggung jawab adalah kesadaran manusia akan tingkah laku atau perbuatannya yang disengaja dan tidak disengaja". Sedangkan Pratiwi dan Yonata (2015, hlm. 334) menjabarkan. 
"Tanggung jawab merupakan unsur penting bagi pengembangan pendidikan karakter karena tanggung jawab adalah sikap dan perilaku seseorang untuk melaksanakan tugas dan kewajibannya, yang seharusnya dia lakukan, terhadap diri sendiri, masyarakat, lingkungan (alam, sosial, dan budaya), negara dan Tuhan Yang Maha Esa"

Berdasarkan pemaparan mengenai dapat disimpulkan bahwa tanggung jawab adalah suatu watak seseorang yang mengerjakan tugas yang telah diberikan kepada dan tidak menhindarinya kecuali memiliki alasan yang jelas dan siap untuk menerima segala risiko yang mungkin terjadi. Menurut Kemendiknas (Prasetya, 2014, hlm. 18) indikator dari nilai tanggung jawab ialah pelaksanaan tugas piket secara teratur. Peran serta aktif dalam kegiatan sekolah. mengajukan usul pemecahan masalah. Menurut Narwanti (dalam Prasetya, 2014, hlm. 19) indikator dari tanggung jawab ialah selalu melaksanakan tugas sesuai dengan aturan/kesepakatan dan bertanggung jawab dengan semua tindakan yang dilakukan. Prasetya (2014, hlm. 17) mengkhususkan indikator nilai tanggung jawab adalah: a) Bertanggung jawab dengan semua tindakan yang dilakukan, b) Memenuhi kewajiban diri, c) Dapat dipercaya. Berdasarkan pernyataan di atas dapat ditarik kesimpulan bahwa indikator tanggung jawab adalah berani menanggung resiko atas tindakan yang dilakukan, melakukan sebaik mungkin, adil, memahami hak dan kewajiban, percaya diri, mampu memanfaatkan lingkungan dengan positif mengendalikan diri, melakukan kewajibannya, menghargai pekerjaan dan, disiplin serta dapat dipercaya.

\section{Disiplin}

Selain karakter tanggung jawab, terdapat pula karakter disiplin dalam berperilaku. Indrawati dan Maksum (2013, hlm. 304) mengartikan kedisiplinan sebagai "...suatu sikap di mana dapat menunjukkan kesiapan dan kesungguhan seseorang saat menghadapi sesuatu.”. Lebih lanjut Juwarsih (2009, hlm. 39) berpendapat bahwa disiplin adalah "cara atau strategi yang digunakan oleh individu dalam proses kegiatan hidup dan kehidupan dengan mengungkapkan apa yang sedang terjadi di masyarakat atau menempatkan sesuatu pada tempatnya". Menurut Schermerhorn (dalam Wulan, 2013, hlm 108) berpendapat mengenai disiplin adalah "tindakan mempengaruhi prilaku melalui teguran". Sedangkan Smith (2011, hlm. 24) disiplin belajar adalah "sesuatu yang sangat dibutuhkan, hal ini disebabkan pembelajaran diarahkan untuk membangun kemampuan berpikir dan kemampuan menguasai materi pembelajaran, dimana pengetahuan itu sumbernya dari luar diri, tetapi di konstruksi dalam diri individu".

Berikutnya Aeni (2011, hlm. 18) mengungkapkan bahwa "disiplin adalah sikap mental untuk mau mematuhi peraturan dan mau bertindak sesuai dengan peraturan secara suka rela". Selanjutnya Fiana, Daharnis, dan Ridha (2013, hlm. 27) menyatakan bahwa "kepatuhaan dan ketaatan siswa terhadap berbagai peraturan dan tat tertib yang berlaku di sekolahnya, itu biasa disebut dengan disiplin siswa. 2) Peraturan, tata tertib dan berbagai ketentuan lainya yang berupaya mengatur perilaku siswa disebut disiplin sekolah". Indraputra dan Sutrisna (2013, hlm. 278) menguatkan dengan berpendapat bahwa "disiplin lebih tepat kalau diartikan sebagai suatu sikap, tingkah laku dan perbuatan yang sesuai dengan peraturan dari organisasi baik yang tertulis maupun yang tidak tertulis".

Dari pengertian di atas, dapat disimpulkan bahwa disiplin adalah suatu sikap seseorang mematuhi, menerima ataupun mentaati segala norma atau tata tertib yang berlaku dengan penuh kesadaran. Sikap disiplin menjadi salah satu faktor untuk menciptakan lingkungan yang aman dan tertib.

Kedisiplinan diperlukan untuk membentuk anak menjadi generasi berkarakter dan memiliki kemampuan dalam mengembangkan prestasi kehidupannya, dengan kedisiplinan yang 
dimiliki seseorang maka seseorang tersebut akan memiliki karakter diri yang baik (Ainia, 2012, hlm. 4). Dari pemaparan di atas peneliti merumuskan indikator siswa yang dapat dikatakan disiplin di antaranya tepat waktu masuk ke kelas, menggunakan seragam dan atributnya secara lengkap, dan berada di dalam kelas selama kegiatan pembelajaran berlangsung.

\section{METODE PENELITIAN}

Penelitian ini dilakukan dengan menggunakan metode penelitian ini adalah metode penelitian Eksperimen dan peneliti mengambil desain quasi eksperiment research yang merupakan desain yang mempunyai kelompok kontrol, tetapi tidak dapat berfungsi sepenuhnya untuk mengontrol variabel-variabel yang mempengaruhi pelaksanaan eksperimen (Jakni, 2016, hlm. 73) dengan desain Non Equivalent Pretest Postes Group Control Disign. Pada desain ini kelompok eksperimen dan kelompok kontrol tidak dipilih secara random, Sugiyono (2016, hlm. 79). Sebagaimana dimodifikasi pada kolom berikut:

\section{Keterangan:}

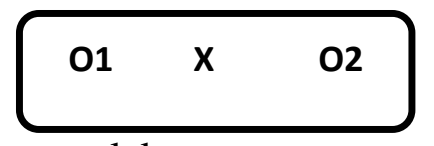

$\mathbf{X} \quad$ : Metode atau perlakuan

O1-O2 : Pencapaian dan peningkatan antara kelas eksperimen

O3-O4 : Pencapaian dan peningkatan antara kelas kontrol

Populasi penelitian ini adaah siswa kelas III se provinsi Jawa Jarat dengan sample yang di ambil yaitu siswa kelas III di kabupaten Purwakarta karena memiliki karakteristik yang sama dengan populasi. Instrumen penelitian digunakan selama kegiatan penelitian kuasi eksperimen berlangsung, hal ini dilakukan untuk membantu kelancaran penelitian dan untuk melihat perkembangan proses eksperimen yang berlangsung. Instrumen yang digunakan dalam penelitian ini di antaranya angket, lembar observasi, jurnal harian siswa, wawancara, dokumentasi, prosedur penelitian. Penelitian ini dilakukan dalam lima tahap alur kegiatan yaitu: tahap persiapan penelitian, pelaksanaan penelitian, analisis data, serta pelaporan dan publikasi. Untuk penentuan kriteria angket menggunakan tabel kriteria di bawah ini:

Tabel 1 . Kriteria Penafsiran Presentase Jawaban Angket

\begin{tabular}{|c|c|}
\hline Kriteria & Penafsiran \\
\hline $\mathrm{P}=0 \%$ & Tak seorang pun \\
\hline $0 \%<\mathrm{P}<25 \%$ & Sebagian kecil \\
\hline $25 \% \leq \mathrm{P}<50 \%$ & Hampir setengahnya \\
\hline $\mathrm{P}=50 \%$ & Setengahnya \\
\hline $50 \%<\mathrm{P}<75 \%$ & Sebagian besar \\
\hline $75 \% \leq \mathrm{P}<100 \%$ & Hamper seluruhnya \\
\hline $\mathrm{P}=100 \%$ & Seluruhnya \\
\hline & (Lestari, dan Yudhanegara, 2017)
\end{tabular}


Untuk lebih jelas berikut diagram tulang ikan (Fishbone) penelitian ini

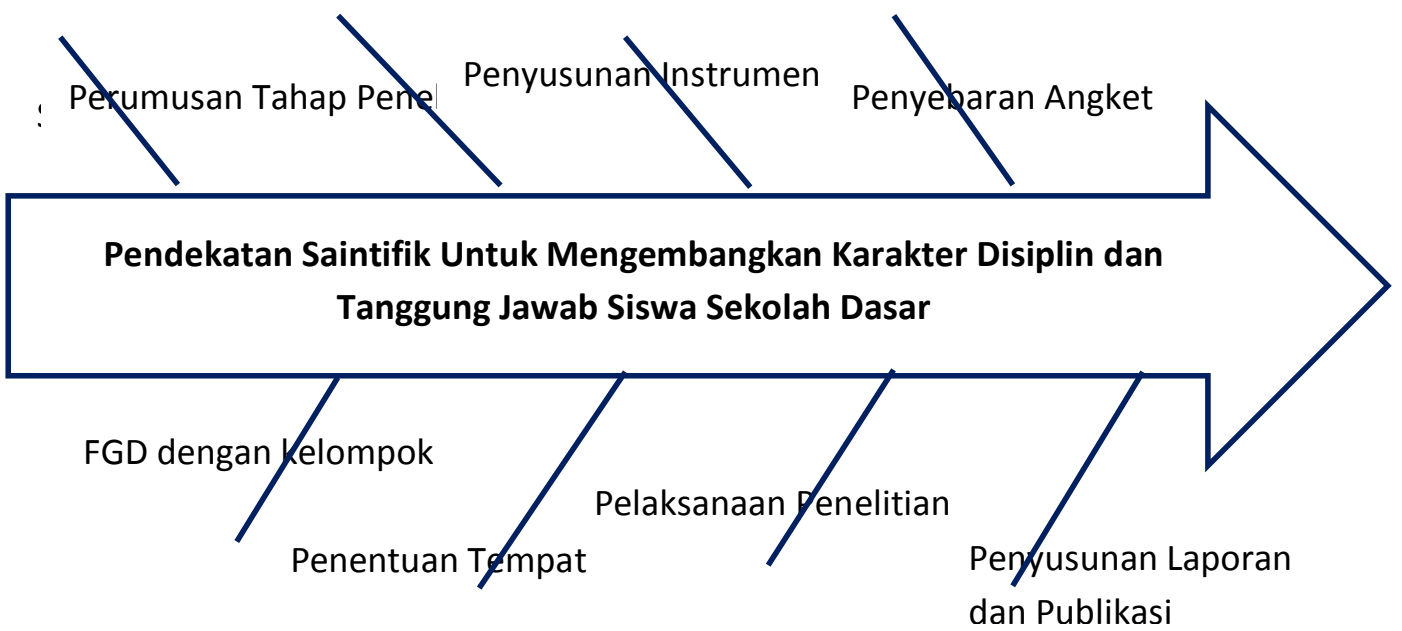

Gambar 1. Diagram Fishbone Penelitian

HASIL DAN PEMBAHASAN

Berikut bagan alur proses penelitian pendekatan saintifik dan konvensional terhadap karakter disiplin dan tanggung jawab siswa.

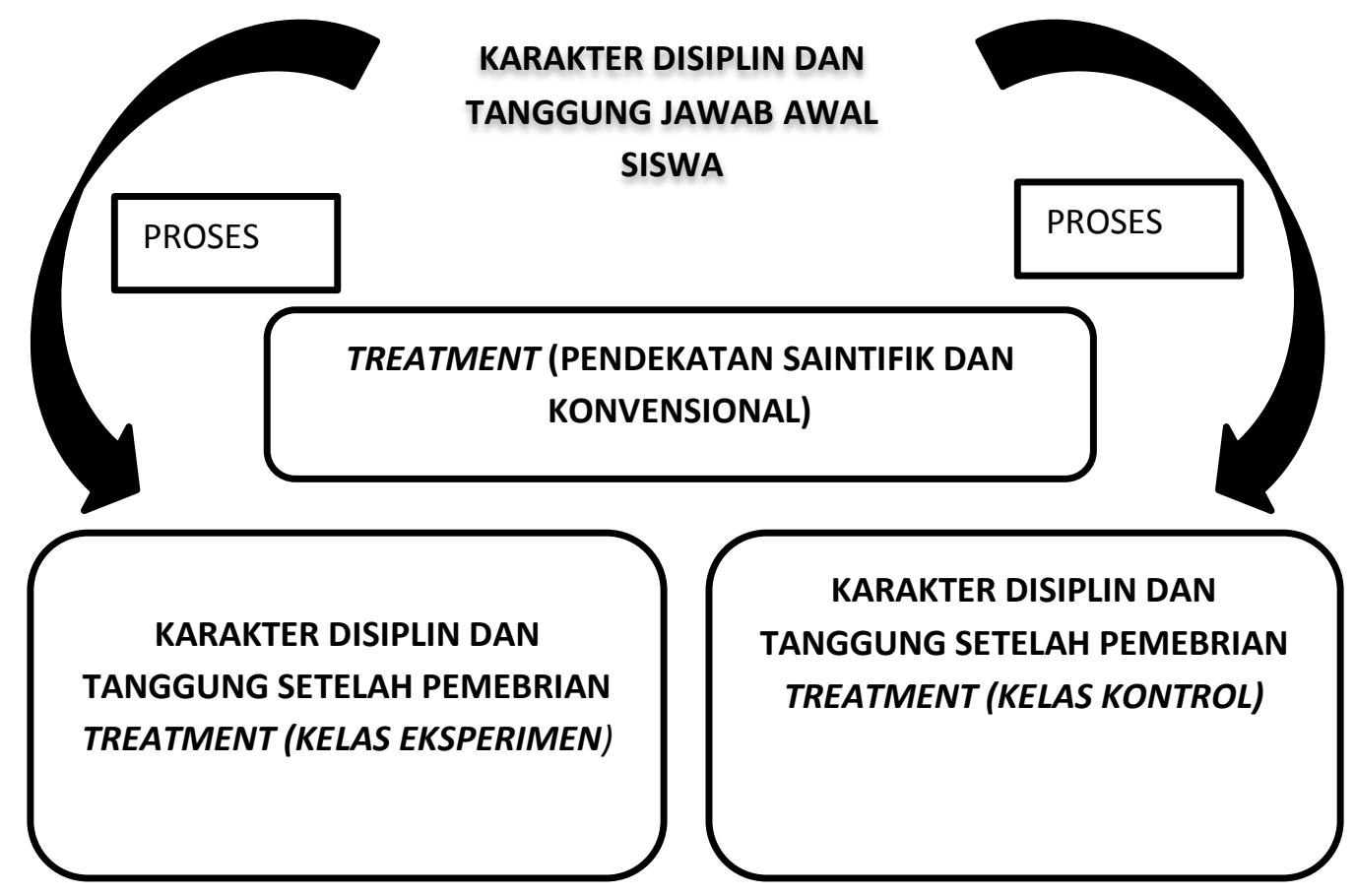

Gambar 2. Alur proses penelitian pendekatan saintifik dan konvensional terhadap karakter disiplin dan tanggung jawab siswa.

\section{Penjelasan Alur}

Alur proses penelitian dapan dijelaskan sebagai berikut, 1) Anak dengan karakter yang belum diberikan perlakuan pedekatan saintifik dan pendekatan konvensional. 2) Proses pemberian perlakuan pendekatan saintifik dengan langkah mengamati, menanya, mencoba, menalar, dan mengkomikasikan $(5 \mathrm{M})$ dan pendekatan konvensional dengan metode 
ceramah. 3) Siswa dengan karakter disiplin dan tanggung jawab setelah diberi perlakuan pendekatan saintifik dan konvensional

Pendekatan saintifik merupakan pembelajaran yang berpusat pada siswa hal ini tentunya saling terkait dengan makna disiplin yaitu disiplin sebagai kondisi yang tercipta dan terbentuk melalui proses dari serangkaian perilaku yang menunjukkan nilai-nilai ketaatan, kepatuhan, kesetiaan, keteraturan atau ketertiban. Nilai-nilai tersebut telah menjadi bagian dalam hidupnya, perilaku itu tercipta melalui proses binaan keluarga, pendidikan dan pengalaman. Prijodarminto (dalam Kamila, 2013, hlm. 12). Di lain pihak melibatkan keterampilan proses sains dalam mengonstruksi konsep, hukum atau prinsip sesuai dengan makna tanggung jawab yang merupakan sikap dan perilaku seseorang untuk melaksanakan tugas dan kewajibannya, yang seharusnya dilakukan, terhadap diri sendiri, masyarakat, lingkungan (alam, sosial dan budaya), negara dan Tuhan Yang Maha Esa. Hasan (dalam Rahayu, 2016, hlm. 97-98). Selanjutnya dalam makna saintifik dapat mengembangkan karakter siswa, pernyataan ini tentu sesuai karena disiplin dan tanggung jawab adalah bagian 18 nilai-nilai karakter.

Presentase rata-rata kelas eksperimen mengalami peningkatan, yang mulanya $60,07 \%$ menjadi 82,86\% dengan kriteria hampir seluruhnya siswa memiliki sikap disiplin. Peningkatan sikap disiplin dan tangggung jawab ini dapat dilihat melalui gambar di bawah ini:

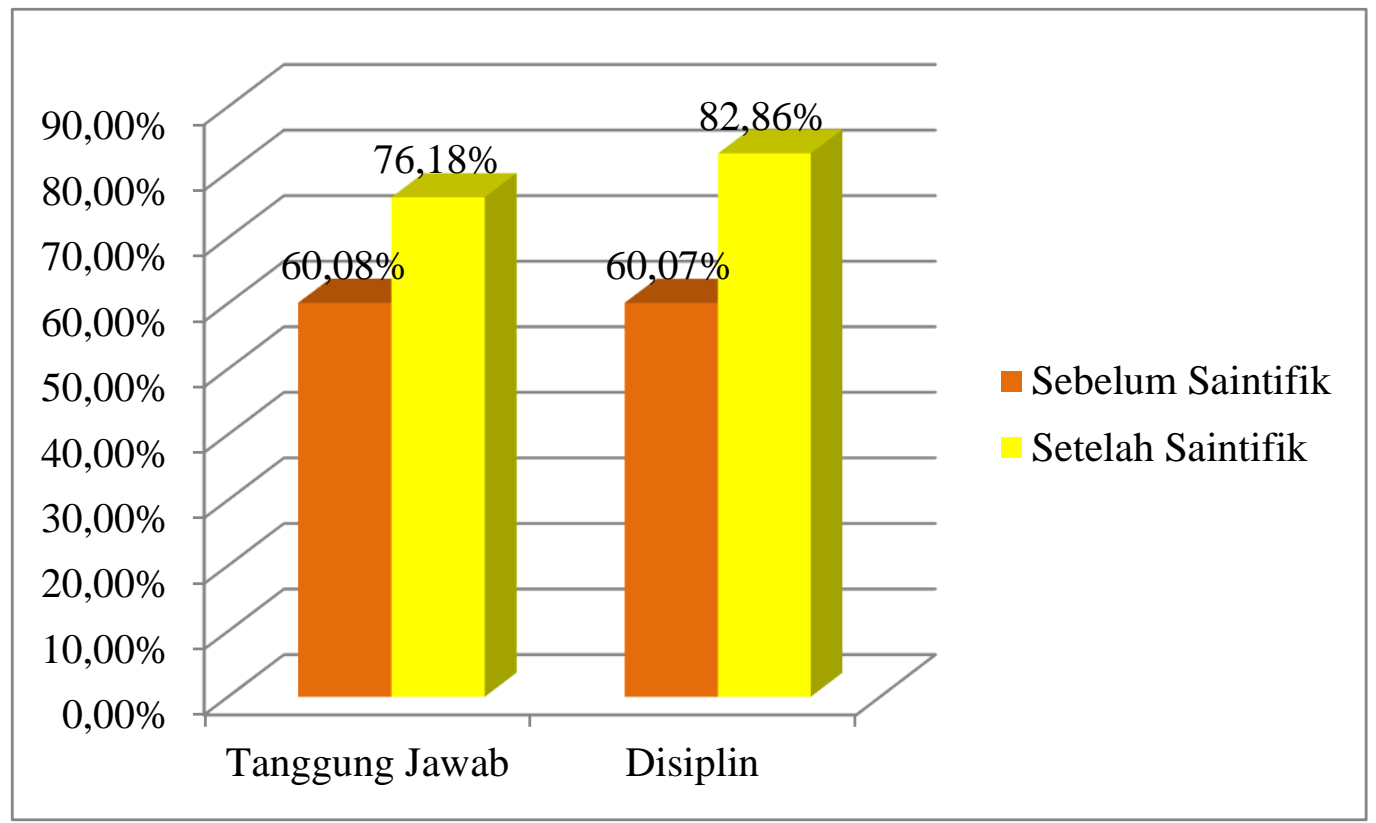

Gambar 3 Peningkatan Karakter Tanggung Jawab dan Disiplin Kelas Eksperimen

Berdasarkan hasil observasi guru di kelas eksperimen, didapatkan hasil bahwa pada pertemuan pertama guru secara keseluruhan mengajar dengan baik dengan total hasil lembar observsi sebesar 70,23\% dimana termasuk kedalam kategori baik. Hasil ini meningkat pada pertemuan selanjutnya, yaitu menjadi $85,71 \%$ dimana termasuk kedalam kategori sangat baik.

Sedangkan hasil dari observasi siswa di pertemuan pertama menunjukan bahwa siswa masih malu-malu di awal pembelajaran. Hal ini dimungkinkan karena para siswa ini masih menyesuaikan dengan guru yang baru mereka kenal hari itu. Namun seiring berjalannya proses pembelajaran siswa terlihat semakin aktif dan partisipatif dalam aktivitas yang diberikan oleh guru. Keaktifan siswa dalam proses pembelajaran ini juga didukung oleh hasil 
dari jurnal harian yang diisi oleh siswa. Dalam jurnal harian hari pertama, mereka menyebutkan bahwa mereka merasa senang selama kegiatan pembelajaran berlangsung dan bersemangat untuk melakukan pembelajaran esok hari.

Peningkatan rata-rata keseluruhan skala awal dan skala akhir sikap disiplin dan tanggung jawab di kelas kontrol dilihat dalam gambar di bawah ini:

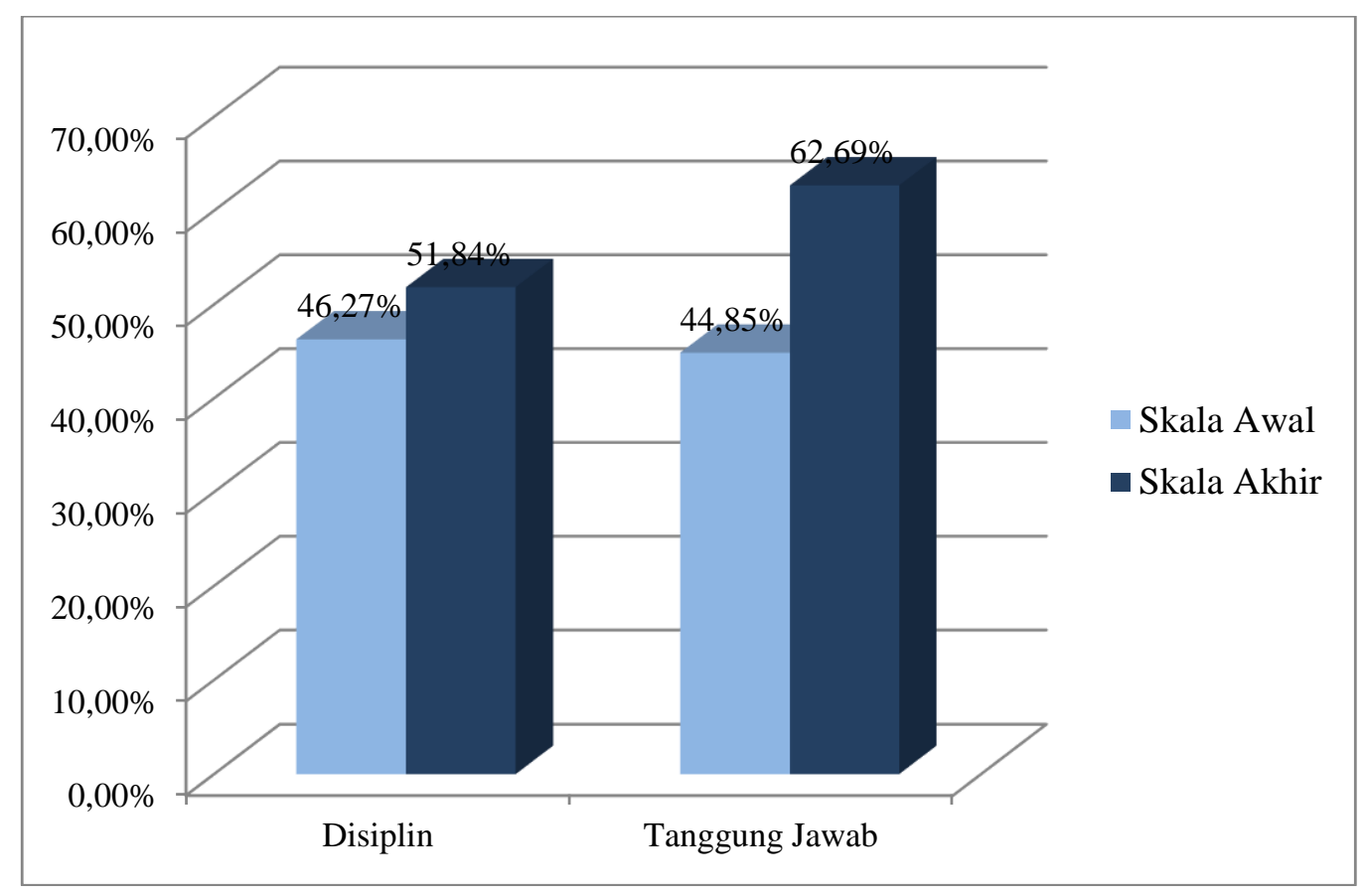

Gambar 4 Peningkatan Karakter Tanggung Jawab dan Disiplin Kelas Kontrol

Berdasarkan hasil observasi siswa dan guru yang dilakukan di kelas kontrol, hasilnya tidak jauh berbeda. Walaupun pembelajaran menggunakan pendekatan konvensional, namun guru dapat membuat siswa aktif dan merasa senang selama kegiatan pembelajaran berlangsung. Hal ini dapat dilihat dari skor observasi guru yang mencapai $73,80 \%$ angka ini menunjukan kategori guru mengajar dengan baik. Selain itu juga, kesimpulan ini diperoleh dari tulisan siswa dalam jurnal harian.

\section{KESIMPULAN}

Simpulan dari penelitian ini adalah secara rata-rata pendekatan saintifik lebih efektif dapat mengembangkan karakter disiplin dan tanggung jawab siswa dibandingkan dengan pembelajaran konvensional. Saran peneliti yaitu totalitas dalam proses kegiatan pembelajaran di kelas maupun di luar kelas dan senantiasa menunjukan perilaku yang menjadi contoh karakter disiplin dan tanggung jawab bagi siswa maupun orang lain.

\section{DAFTAR RUJUKAN}

Aeni, A. N. (2011). Menanamkan Disiplin pada Anak Melalui Dairy Activity Menurut Ajaran Islam. Jurnal Pendidikan Agama Islam-Ta'lim, 17-29.

Ainia, Q., Kurniasih, N., \& Sapti, M. (2012, November 10). Eksperimentasi Model pembelajaran Auditory Intellectually Repitition (AIR) terhadap Prestasi Belajar Matematika Ditinjau dari Karakter Belajar Siswa Kelas VII SMP Negeri SeKecamatan Kaligesing Tahun 2011/2012. Prosiding, 709-716. 
Apriani, A.-N., \& Wangid, M. N. (2015). Pengaruh SSP Tematik-Integratif terhadap Karakter Disiplin dan Tanggung Jawab Siswa Kelas III SD. Jurnal Prima Edukasia, $12-25$.

Aulina, C. N. (2013). Penanaman Disiplin pada Anak Usia Dini. Pedagogia, 36-49.

Batmalo, J. B. (2016). Implementasi Pendekatan Saintifik dalam Pembelajaran Tematik Integratif pada Kelas V Sekolah Dasar Negeri Nirmala Bantul. Jurnal Pendidikan Guru Sekolah Dasar, 471-478.

Depdiknas RI. (2003). Undang-undang No 20 Tahun 2003 tentang Sistem Pendidikan Nasional. Jakarta: Depdiknas.

Dikbud RI. (2003). Undang-Undang Sistem Pendidikan Nasional. Jakarta: Dikbud KBRI Tokyo.

Dyahwati, P., Rahayu, E. S., \& Susanti, R. (2013). Pengembangan Perangkat Pembelajaran Berbasis Masalah pada Materi Sistem Pencernaan Makanan Bervisi Pendidikan Karakter. Journal of Educational Research and Evaluation, 2, 26-31.

Hosnan, M. (2014). Pendekatan Saintifik dan Kontekstual dalam Pembelajaran Abad 21: Kunci Sukses Implementasi Kurikulum 2013. Ghalia Indonesia.

Indraputra, T., \& Sutrisna, E. (2013). Disiplin, Motivasi, Budaya Kerja, dan Kinerja. Jurnal Administrasi Pembangunan, 219-323.

Jakni. (2016). Metodologi Penelitian Eksperimen Bidang Pendidikan. Bandung: Alfabeta.

Juwarsih. (2009). Upaya Guru IPS Sejarah dalam Menciptakan Disiplin Siswa di SMP Nailul Amin Kec. Arahan Kab. Indramayu. [SKRIPSI]: Sekolah Tinggi Pangeran Dharma Kusuma Segeran Indramayu.

Lestari, K. E., \& Yudhanegara, M. R. (2017). Penelitian Pendidikan Matematika. Bandung: PT Refika Aditama.

Lickona , T. (2015). Educating for Character-Mendidik untuk Membentuk Karakter (Bagaimana Sekolah dapat Mengajarkan Sikap Hormat dan Tanggung Jawab. Jakarta: Bumi Aksara.

Lubis, A. (2012). Pengaruh Model Pembelajaran Kooperatif Tipe STAD terhadap Hasil Belajar Fisika Siswa pada Materi Pokok Gerak Lurus di Kelas X SMA Swasta UISU Medan. Jurnal Pendidkan Fisika, 27-32.

Machin, A. (2014). Implementasi Pendekatan Saintifik, Penamanan Karakter dan Konservasi pada Pembelajaran Materi Pertumbuhan. Jurnal Pendidikan IPA Indonesia, 28-35.

Marjan, J., Arnyana, I. P., \& Setiawan, I. N. (2014). Pengaruh Pembelajaran Pendekatan Saintifik Terhadap Hasil Belajar Biologi dan Keterampilan Proses Sains Siswa MA Mu'allimat NW Pancor Selong Kabupaten Lombok Timur Nusa Tenggara Barat. eJournal Program Pascasarjana Universitas Pendidikan Ganesha, 4.

Maryani, I., \& Fatmawati, L. (2016). Pendekatan Scientifik dalam Pembelajaran di Sekolah Dasar (Teori dan Praktik. Sleman: Deepublish.

Mulyasa, E. (2014). Pengembangab dan Implementasi Kurikulum 2013. (A. S. Wardan, Ed.) Bandung: Remaja Rosdakarya. 
Pasani, C. F., Sumartono, \& Sridevi, H. (2016). Mengembangkan Karakter Tanggung Jawab Ssiwa melalui Pembelajaran Model Kooperatif Tipe Number Head Together. EDUMAT Jurnal Pendidikan Matematika, 4.

Prasetya, A. B. (2014). Penerapan Pendidikan Karakter Nilai Disiplin dan Nilai Tanggung jawab dalam Mata Pelajaran Pendidikan Jasmani, Olahraga, dan Kesehatan (PJOK) di Kelas I dan IV SD Negeri Percobaan 3. [SKRIPSI]: UNY. Tidak Diterbitkan.

Pratiwi, A. H., \& Yonata, B. (2015). Karakter Tanggung Jawab Siswa pada Materi Hidrolisis Garam Kelas XI SMAN 18 Surabaya melalui Penerapan Model Pembelajaran Kooperatif Tipe Jigsaw. UNESA Journal of Chemical Education, 333-339.

Putra, D. P., Thahar, H. E., \& Nurizzati. (2013). Profil Tokoh Pendidik dalam Novel Burlian Karya Tere-Liye. Jurnal Bahasa dan Sastra, 1.

Rahayu, R. (2016). Peningkatan Karakter Tanggung Jawab Siswa SD Melalui Penilaian Produk pada Pembelajaran Mind Mappng. Jurnal Konseling GUSJIGANG, 97-103.

Sadulloh, U., Robandi, B., \& Muharam, A. (2006). Pedagogik. Bandung: UPI PRESS.

Smith, M. B. (2011). Pengaruh Layanan Konseling Kelompok terhadap Disiplin Belajar Siswa di SMA Negeri 1 Atinggola Kabupaten Gorontalo Utara. Jurnal Penelitian dan Pendidikan, 22-32.

Suartama, I. K. (2010, Oktober). Pengembangan Multimedia untuk Meningkatkan Kualitas Pembelajaran pada Mata Kuliah Media Pembelajaran. Jurnal Pendidikan dan Pengajaran, 253-262.

Sufairoh. (2016). Pendekatan saintifik dan Model Pembelajaran K-13. Jurnal Pendidikan Profesional, 116-125.

Sugiyono. (2016). Metode Penelitian Kuantitatif, Kualitatif, dan R\&D. Bandung: Alfabeta.

Sulastri. (2015). Implementasi Pendekatan Saintifik dalam Pembelajaran PAI di SMP NegeriI 2 dan SMP Negeri 5 Kota Bandung 2015. Tarbawy, 68-81.

Sumayasa, I. N., Marhaeni, A. A., \& Dantes, N. (2015). Pengaruh ImpIementasi Pendekatan Saintifik terhadap Motivasi Belajar dan Hasil BEelajar Bahasa Indonesia pada Siswa Kelas VI di Sekolah Dasar Se Gugus VI Kecamatan Abang, Karangasem. e- Journal Program Pascasarjana Universitas Pendidikan Ganesha, 5.

Ulum, M. M., \& Wulandari, R. D. (2013). Faktor yang Mempengaruhi Kepatuhan Pendokmentasian Asuhan Keperawatan Berdasarkan Teori Kepatuhan Milogram. Jurnal Administrasi Kesehatan Indonesia, 252-262.

Wartini, I. A., Lasmawan, I. W., \& Marhaeni, A. A. (2014). Pengaruh Implementasi Pendekatan Saintifik terhadap Sikap Sosial dan Hasil Belajar PKn dI Kelas VI SD Jembatan Budaya, Kuta. e-Journal Program Pascasarjana Universitas Pendidikan Ganesha, 4.

Wulan, S. (2011). Hubungan Disiplin dengan Kinerja Guru SMA Negeri di Tiga Kecamatan Kota Depok. Jurna Ilmiah WIDYA, 106-112.

Yantiani, N. M., Wiarta, I. W., \& Putra, M. (2013). Pembelajaran Kooperatif Pair Check Berpengaruh terhadap Hasil Belajar Materi Bangun Ruang dan Bangun Datar Siswa Kelas IV Gugus IV Semarapura. Mimbar PGSD. 